\title{
Effects of KB-5492, a New Anti-Ulcer Agent, on Ethanol- and Acidified Aspirin-Induced Gastric Mucosal Damage In Vivo and In Vitro
}

\author{
Yasuo Morimoto, Shinya Oshima, Hideaki Hara and Takayuki Sukamoto \\ Department of Pharmacology, New Drug Research Laboratories, Kanebo Ltd, 1-5-90, Tomobuchi-cho, Miyakojima-ku, Osaka 534, Japan
}

Received June 30, $1993 \quad$ Accepted October 12, 1993

\begin{abstract}
The effects of KB-5492, a new anti-ulcer agent with selective affinity for the sigma receptor, on ethanol- and acidified aspirin-induced gastric mucosal damage were studied in vivo and in vitro and compared with those of 16,16-dimethyl prostaglandin $E_{2}\left(d m P G E_{2}\right)$. In the in vivo study, KB-5492 (200 mg $/ \mathrm{kg}$, p.o.) as well as $\mathrm{dmPGE}_{2}(0.01 \mathrm{mg} / \mathrm{kg}$, p.o.) significantly prevented the acute macroscopic lesions in rat gastric mucosa induced by oral administration of either absolute ethanol or $80 \mathrm{mM}$ aspirin in $150 \mathrm{mM} \mathrm{HCl}$. The light microscopic examination revealed that KB-5492 almost completely prevented the deep mucosal lesions induced by these necrotizing agents. KB-5492 also prevented the exfoliation of surface epithelial cells, but its preventive effect was incomplete. In the in vitro study, gastric epithelial cells, isolated from the rat stomach, were cultured for 6 days until they reached confluency. Subsequently, ${ }^{51} \mathrm{Cr}$ was incorporated into the cells. Both $10 \mathrm{mM}$ aspirin (at $\mathrm{pH} \mathrm{5.0)}$ and $12.5 \%$ ethanol (at $\mathrm{pH} \mathrm{7.4)} \mathrm{induced} \mathrm{damage} \mathrm{to} \mathrm{the} \mathrm{cells} \mathrm{and}$ markedly increased ${ }^{51} \mathrm{Cr}$ release from the cells. KB-5492 at 0.3 and $1 \mathrm{mM}$ and $\mathrm{dmPGE}_{2}$ at 0.3 and $1 \mu \mathrm{M}$ significantly, but not completely, prevented both the aspirin- and ethanol-induced increases in ${ }^{51} \mathrm{Cr}$ release from the cells. These findings indicate that KB-5492 as well as $\mathrm{dmPGE}_{2}$ may exert a direct but limited protective effect on the surface epithelial cells in vivo.
\end{abstract}

Keywords: KB-5492, Anti-ulcer agent, Prostaglandin, Gastric epithelial cell, Gastric mucosal protection

KB-5492, 4-methoxyphenyl 4-(3,4,5-trimethoxybenzyl)-1-piperazineacetate monofumarate monohydrate, is a new anti-ulcer agent previously shown to prevent various experimental gastric mucosal lesions in rats including those induced by oral administration of absolute ethanol and acidified aspirin $(1,2)$. Although KB-5492, at antiulcer doses, did not affect either basal or histamine-stimulated gastric acid secretion in rats $(1,2)$, it increased gastric mucosal blood flow and prevented aspirin-induced reduction of gastric mucus (2). Therefore, KB-5492 has been considered to enhance gastric mucosal defensive factors.

Recently, sigma-receptors have been reported to exist in many organs such as the brain (3), liver (4) and spleen (5). Furthermore, sigma-receptors are abundant in the mucosal and submucosal plexus of the gastric fundus and duodenum in guinea pig and human $(6,7)$. Sigma receptor ligand, 1,3-di(2-tolyl) guanidine (DTG), stimulates duodenal alkaline secretion and shows protective effects on various gastric lesions in rats through a sigma receptor $(8,9)$. Thus, sigma receptors may play an important role in the control of mucosal function. KB-5492 was found to have a selective affinity for the sigma receptor in guinea pig brain and porcine fundic mucosa (Y. Harada et al., unpublished data).

In the present study, the effects of KB-5492 on ethanoland acidified aspirin-induced gastric mucosal damage were investigated in vivo and in vitro to clarify whether a direct protective effect on the gastric mucosal cells is involved in the mechanism of gastric mucosal protection by KB-5492.

\section{MATERIALS AND METHODS}

Animals

In the in vivo studies, male Sprague-Dawley rats weighing 210-240 g (Charles River Japan, Atsugi) were used. The animals were fasted but were allowed free access to water for $24 \mathrm{hr}$ before the experiments. In the in vitro studies, 5- to 10-day-old Sprague-Dawley rats (Clea Japan, Osaka) were used.

\section{In vivo studies}

Effects of drugs on ethanol- and acidified aspirin-induced gastric mucosal lesions: One milliliter of absolute 
ethanol (Wako, Osaka) or $80 \mathrm{mM}$ aspirin (Wako) suspended in $150 \mathrm{mM} \mathrm{HCl}$ was administered to the rat orally. After $1 \mathrm{hr}$, the animals were killed. The stomach was removed, fixed by inflation with $12 \mathrm{ml}$ of $1 \%$ formalin, and then incised along the greater curvature. The length $(\mathrm{mm})$ of each lesion formed on the glandular portion was measured under a dissecting microscope, and the sum of the length of the lesions in each animal was calculated. For histological examination, the stomach was spread on cardboard and immersed in 10\% phosphate-buffered formalin ( $\mathrm{pH} \mathrm{7.0)} \mathrm{for} 48 \mathrm{hr}$. A small specimen of the tissue was cut out from a non-necrotic lesion area of the fundic mucosa. The tissue was embedded in paraffin and sliced into $4-\mu \mathrm{m}$ sections. Subsequently, the sections were stained with hematoxylin and eosin.

KB-5492 (Kanebo, Osaka) suspended in 1\%0 gum arabic solution, or 16,16-dimethyl prostaglandin $\mathrm{E}_{2}\left(\mathrm{dmPGE}_{2}\right.$, Cayman Chemical, Ann Arbor, MI, USA) dissolved initially in absolute ethanol and then diluted with $1 \%$ gum arabic solution was administered orally $30 \mathrm{~min}$ before ethanol or aspirin treatment.

\section{In vitro studies}

Isolation and culture of gastric epithelial cells: The experiment was performed according to the method of Terano et al. (10). The stomach of 5- to 10-day-old rats was removed, and the corpus area was isolated and then minced. The minced tissues were suspended in Coon's modified Ham's F-12 medium (KC Biological, Lenexa, KS, USA) containing $0.1 \%$ collagenase (Wako), $0.05 \%$ hyaluronidase (Type I-S; Sigma, St. Louis, MO, USA), $100 \mathrm{U} / \mathrm{ml}$ penicillin $\mathrm{G}$ potassium (Meiji Seika, Tokyo), $100 \mu \mathrm{g} / \mathrm{ml}$ streptomycin sulfate (Meiji Seika) and 100 $\mu \mathrm{g} / \mathrm{ml}$ gentamicin sulfate (Sigma), and then incubated at $37^{\circ} \mathrm{C}$ for $1 \mathrm{hr}$. The tissues were filtered through a nylon mesh and the filtrate was washed with Hank's balanced salt solution (HBSS; Nissui, Tokyo). The cell pellet was resuspended in Coon's modified Ham's F-12 medium containing 10\% heat-inactivated fetal bovine serum (Gibco, Gaithersburg, MD, USA), $15 \mathrm{mM}$ HEPES (Dojindo Laboratories, Kumamoto), $2 \mu \mathrm{g} / \mathrm{ml}$ fibronectin (Sigma) and the same antibiotics as described above. Subsequently, the cells were seeded in 96-well tissue culture plates (Corning, Corning, NY, USA) at $5 \times 10^{4}$ cells $/$ well and cultured at $37^{\circ} \mathrm{C}$ for 6 days in a humidified atmosphere containing $5 \% \mathrm{CO}_{2}$ in air until they reached confluency.

Chromium-51 loading: The experiment was also performed according to the method of Terano et al. (11). The medium was discarded and the cells were washed with HBSS. The cells were incubated at $37^{\circ} \mathrm{C}$ for $2 \mathrm{hr}$ in HBSS containing $370 \mathrm{kBq} / \mathrm{ml}{ }^{51} \mathrm{Cr}$ (sodium chromate, $14.8-44.4 \mathrm{TBq} / \mathrm{g} \mathrm{Cr}$, New England Nuclear, Boston, MA, USA) and then washed with HBSS to remove excess isotope.

Measurement of ${ }^{51} \mathrm{Cr}$ release: Both test drugs (i.e., KB5492 and $\mathrm{dmPGE}_{2}$ ) and damaging agents (i.e., aspirin and ethanol) were dissolved in HBSS. In the study on aspirin-induced damage, ${ }^{51} \mathrm{Cr}$-preloaded cells were incubated at $37^{\circ} \mathrm{C}$ for $2 \mathrm{hr}$ in the following solutions adjusted to $\mathrm{pH}$ 5.0: (a) HBSS plus $10 \mathrm{mM}$ aspirin, (b) test drug plus 10 $\mathrm{mM}$ aspirin, (c) HBSS alone and (d) test drug alone. After incubation, the radioactivity of ${ }^{51} \mathrm{Cr}$ released into the supernatant was counted with a Gamma Counter (A-5210; Packard, Meriden, CT, USA). The radioactivity of ${ }^{51} \mathrm{Cr}$ in the cells was also counted after the cells were solubilized with $1 \mathrm{~N} \mathrm{NaOH}$. Subsequently, ${ }^{51} \mathrm{Cr}$ release $(\%)$ was calculated as follows:

$$
{ }^{51} \mathrm{Cr} \text { Release }(\%)=\frac{\mathrm{cpm} \text { in the supernatant }}{\text { cpm in the supernatant }+ \text { cpm in the cells }}
$$

In the study on ethanol-induced damage, test drugs, dissolved in HBSS and adjusted to $\mathrm{pH} 7.4$, were preincubated with ${ }^{51} \mathrm{Cr}$-preloaded cells at $37^{\circ} \mathrm{C}$ for $20 \mathrm{~min}$, and the cells were incubated for $10 \mathrm{~min}$ after the exposure to $12.5 \%$ ethanol. Subsequently, ${ }^{51} \mathrm{Cr}$ release was calculated in the same manner as described above.

\section{Statistics}

Results were expressed as the mean \pm S.E. Statistical significance was determined by one-way analysis of variance followed by Dunnett's or Duncan's test.

\section{RESULTS}

\section{Effects of drugs on ethanol- and acidified aspirin-induced gastric mucosal lesions}

As shown in Fig. 1, oral administration of absolute

Table 1. Effects of KB-5492 and 16,16-dimethyl prostagland in $\mathbf{E}_{2}$ on ethanol- and acidified aspirin-induced gastric mucosal lesions in rats

\begin{tabular}{lcccc}
\hline Drug & $\begin{array}{c}\text { Dose } \\
\left(\mathrm{mg} / \mathrm{kg}, \mathrm{p} . \mathrm{o}^{\prime}\right)\end{array}$ & $\begin{array}{c}\text { No. of } \\
\text { rats }\end{array}$ & $\begin{array}{c}\text { Lesion length } \\
(\mathrm{mm})\end{array}$ & $\begin{array}{c}\text { Inhibition } \\
(\%)\end{array}$
\end{tabular}

(1) Absolute ethanol-induced lesions

$\begin{array}{lcccc}\text { Control } & - & 6 & 159 \pm 18 & - \\ \text { KB-5492 } & 200 & 6 & 27 \pm 4^{* *} & 83 \\ 16,16-\text { dmPGE }_{2} & 0.01 & 6 & 13 \pm 4^{* *} & 92\end{array}$

(2) Acidified aspirin-induced lesions

$\begin{array}{lcccc}\text { Control } & - & 6 & 143 \pm 14 & - \\ \text { KB-5492 } & 200 & 6 & 20 \pm 8^{* *} & 86 \\ 16,16-d m \text { CGE }_{2} & 0.01 & 6 & 14 \pm 6^{* *} & 90\end{array}$

One milliliter of absolute ethanol or $80 \mathrm{mM}$ aspirin in $150 \mathrm{mM} \mathrm{HCl}$ was administered orally and the stomach was removed $1 \mathrm{hr}$ later. Drugs were administered orally $30 \mathrm{~min}$ before ethanol or acidified aspirin treatement. Values are expressed as the mean \pm S.E. ${ }^{* *} \mathrm{P}<0.01$, significantly different from the control (Dunnett's test). 


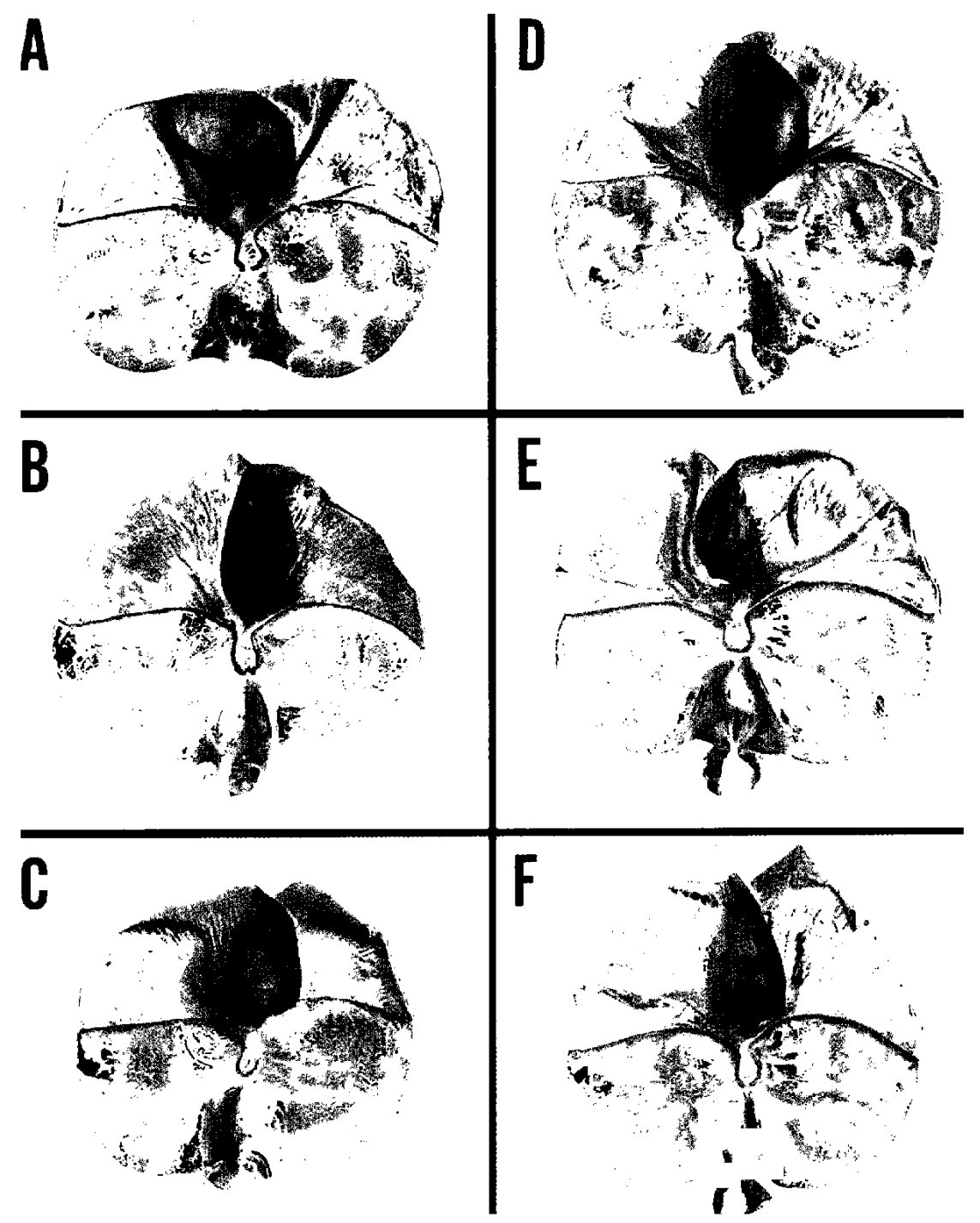

Fig. 1. Macroscopic appearance of rat gastric mucosa $1 \mathrm{hr}$ after the oral administration of absolute ethanol and acidified aspirin. One milliliter of absolute ethanol or $80 \mathrm{mM}$ aspirin in $150 \mathrm{mM} \mathrm{HCl}$ was administered orally and the stomach was removed $1 \mathrm{hr}$ later. Drug or vehicle (1\% gum arabic) was administered orally $30 \mathrm{~min}$ before ethanol or acidified aspirin treatment. A: vehicle + absolute ethanol, B: KB-5492 $(200 \mathrm{mg} / \mathrm{kg})+$ absolute ethanol, C: dmPGE $(0.01 \mathrm{mg} / \mathrm{kg})+$ absolute ethanol, D: vehicle + acidified aspirin, E: KB-5492 $(200 \mathrm{mg} / \mathrm{kg})+$ acidified aspirin, F: dmPGE $(0.01 \mathrm{mg} / \mathrm{kg})+$ acidified aspirin.

ethanol and that of $80 \mathrm{mM}$ aspirin in $150 \mathrm{mM} \mathrm{HCl}$ both induced macroscopic lesions in the gastric mucosa $1 \mathrm{hr}$ later. KB-5492 and dmPGE 2 , administered orally at 200 and $0.01 \mathrm{mg} / \mathrm{kg}$, respectively, prevented these lesions. As shown in Table 1 , both drugs significantly reduced the lesion length as compared with the control.

\section{Light microscopic observations}

Figures 2 and 3 show the typical microscopic appearances of the gastric mucosa obtained $1 \mathrm{hr}$ after the oral administration of absolute ethanol and acidified aspirin, respectively. Not only the exfoliation of surface epithelial cells, but also lesions reaching the deeper layers were ob- served in the gastric mucosa exposed to absolute ethanol and acidified aspirin. KB-5492 and $\mathrm{dmPGE}_{2}$, administered orally at 200 and $0.01 \mathrm{mg} / \mathrm{kg}$, respectively, almost completely prevented the deep mucosal lesions. Both drugs also prevented the exfoliation of surface epithelial cells, but their preventive effects were incomplete.

\section{Effects of drugs on ethanol-and aspirin-induced damage} to cultured gastric epithelial cells

More than $90 \%$ of the cultured cells were histochemically identified as mucus-producing epithelial cells by periodic acid-Schiff staining, which was consistent with the result obtained by Terano et al. $(10-12)$. 


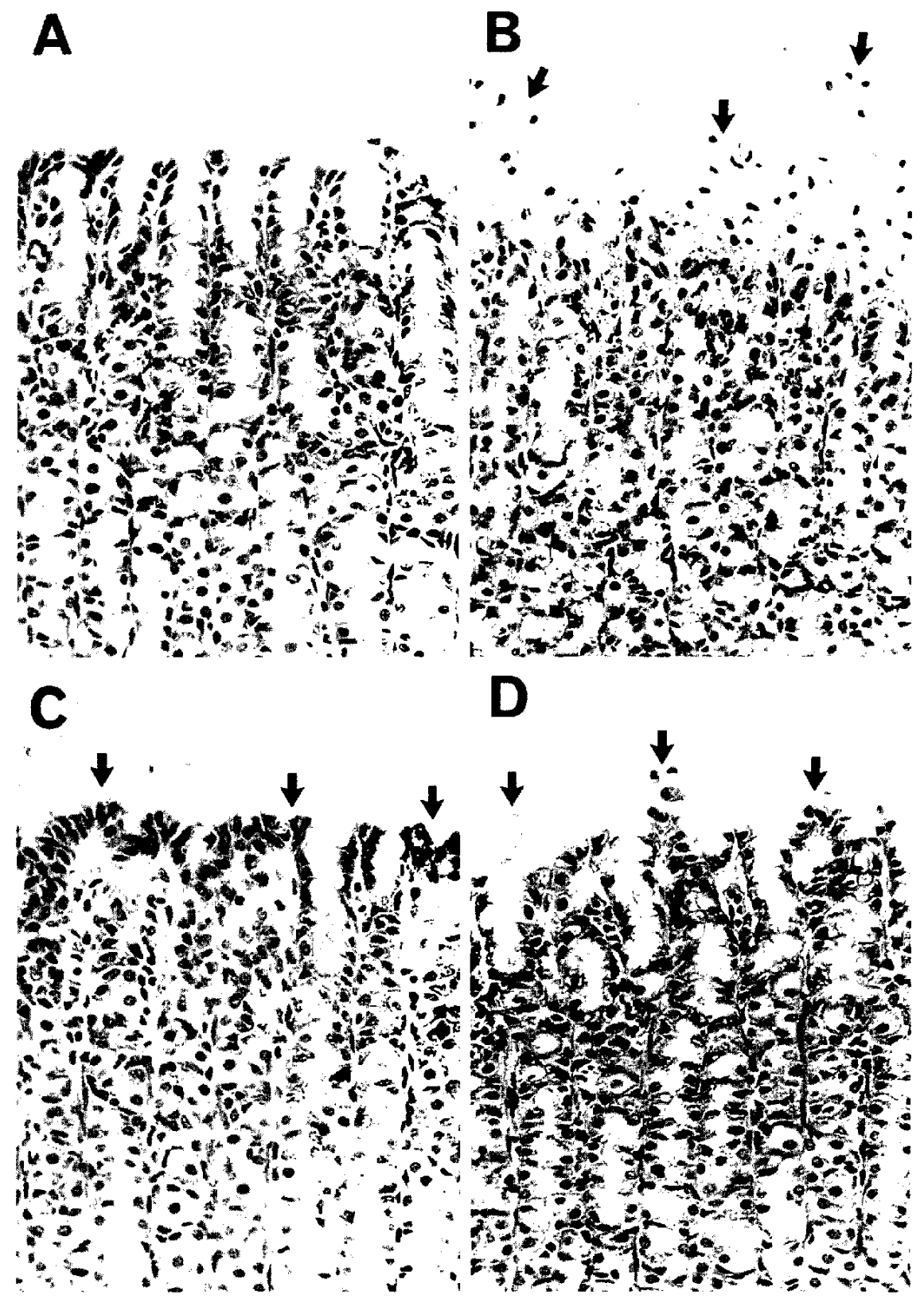

Fig. 2. Light microscopy of rat gastric mucosa $1 \mathrm{hr}$ after the oral administration of absolute ethanol. The exfoliation of surface epithelial cells is indicated by arrows. A: normal, B: vehicle + absolute ethanol, C: KB-5492 $(200 \mathrm{mg} / \mathrm{kg})+\mathrm{absolute}$ ethanol, D: dmPGE $(0.01 \mathrm{mg} / \mathrm{kg})+$ absolute ethanol. Hematoxylin and eosin staining $(\times 300)$.

As shown in Fig. 4, 12.5\% ethanol markedly increased the ${ }^{51} \mathrm{Cr}$ release from cultured gastric epithelial cells. KB5492 at 0.3 and $1 \mathrm{mM}$ significantly and concentration-dependently prevented the ethanol-induced increase in ${ }^{51} \mathrm{Cr}$ release from the cells. $\mathrm{DmPGE}_{2}$ slightly but significantly prevented the increase in ${ }^{51} \mathrm{Cr}$ release at $0.1,0.3$ and 1 " $\mathbf{M}$.

As shown in Fig. 5, $10 \mathrm{mM}$ aspirin also markedly increased the ${ }^{51} \mathrm{Cr}$ release from the cells. KB-5492 at 0.3 and $1 \mathrm{mM}$ and $\mathrm{dmPGE}_{2}$ at 0.3 and $1 \mu \mathrm{M}$ slightly but sig- nificantly and concentration-dependently prevented the aspirin-induced increase in ${ }^{51} \mathrm{Cr}$ release.

Neither $1 \mathrm{mM} \mathrm{KB}-5492$ nor $1 \mu \mathrm{M} \mathrm{dmPGE} 2$ alone affected the ${ }^{51} \mathrm{Cr}$ release from the cells.

\section{DISCUSSION}

In the present study, KB-5492 at an anti-ulcer dose of $200 \mathrm{mg} / \mathrm{kg}(1,2)$, as well as $\mathrm{dmPGE}_{2}$ at $0.01 \mathrm{mg} / \mathrm{kg}(13$, 14), prevented the acute macroscopic lesions in rat gastric 

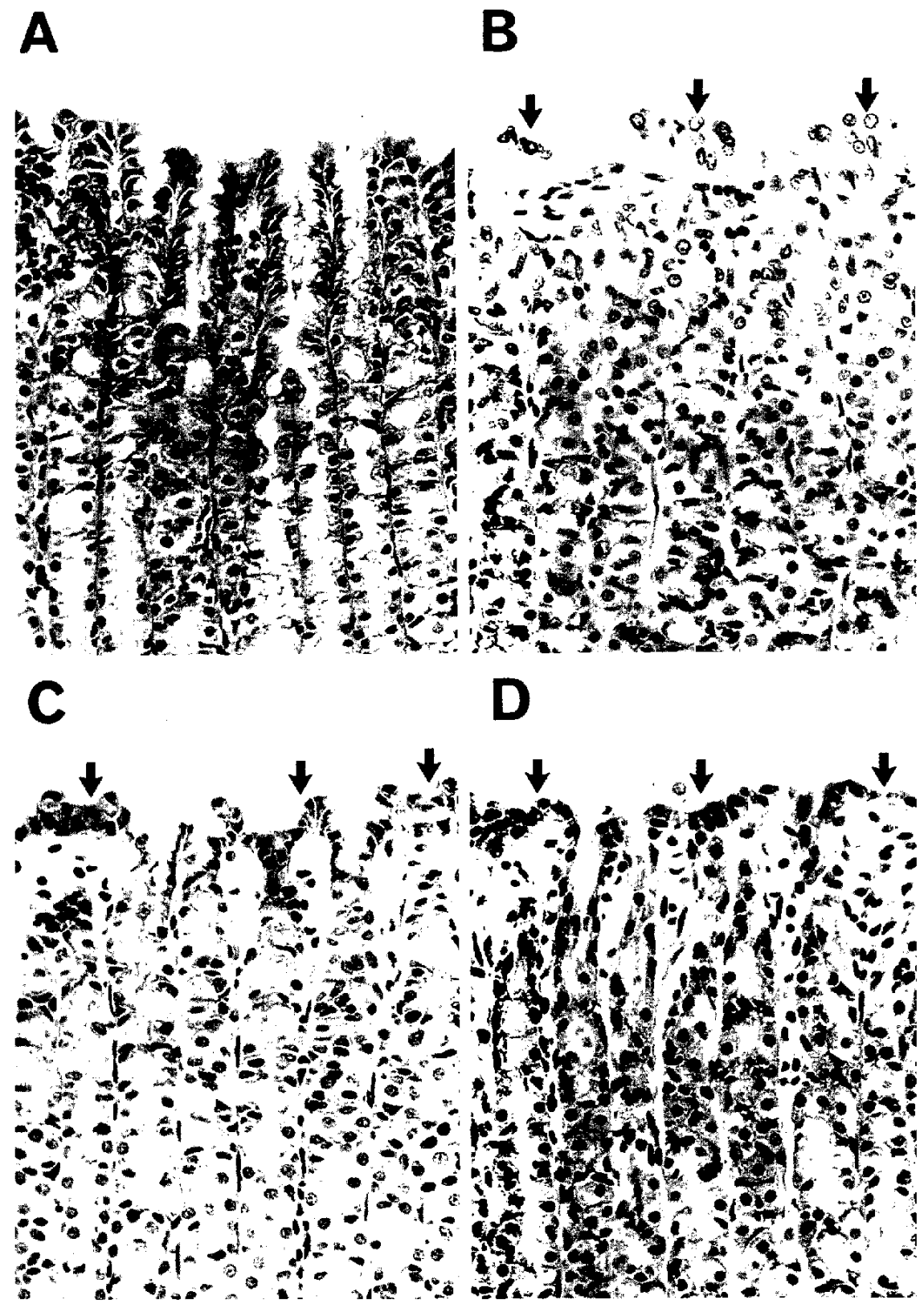

Fig. 3. Light microscopy of rat gastric mucosa $1 \mathrm{hr}$ after the oral administration of $80 \mathrm{mM}$ aspirin in $150 \mathrm{mM} \mathrm{HCl}$. The exfoliation of surface epithelial cells is indicated by arrows. A: normal, B: vehicle + acidified aspirin, C: KB-5492 (200 mg/kg) + acidified aspirin, $\mathrm{D}: \mathrm{dmPGE}(0.01 \mathrm{mg} / \mathrm{kg})+$ acidified aspirin. Hematoxylin and eosin staining $(\times 300)$.

mucosa induced by oral administration of either absolute ethanol or $80 \mathrm{mM}$ aspirin in $150 \mathrm{mM} \mathrm{HCl}$. However, in the light microscopic examination, the preventive effects of KB-5492 and dmPGE 2 on the exfoliation of surface epithelial cells induced by these necrotizing agents were incomplete. Our result that $\mathrm{dmPGE}_{2}$ did not completely prevent the ethanol-induced damage to surface epithelial cells is consistent with those obtained by Lacy and Ito (15), Tarnawski et al. (16) and Schmidt et al. (17). However, our result that $\mathrm{dmPGE}_{2}$ did not completely pre- vent aspirin-induced damage to surface epithelial cells is inconsistent with that obtained by Ohno et al. (18). This discrepancy may be due to the difference in experimental conditions between our study and theirs; the gastric mucosa was exposed to 30 or $100 \mathrm{mg} / \mathrm{kg}$ of aspirin suspended in $1 \%$ carboxymethylcellulose for $10 \mathrm{~min}$ in the study by Ohno et al. (18), whereas the mucosa was exposed to $80 \mathrm{mM}(72 \mathrm{mg} / \mathrm{kg})$ aspirin suspended in $150 \mathrm{mM} \mathrm{HCl}$ for $60 \mathrm{~min}$ in our study.

Tarnawski et al. (16) have suggested that the integrity 

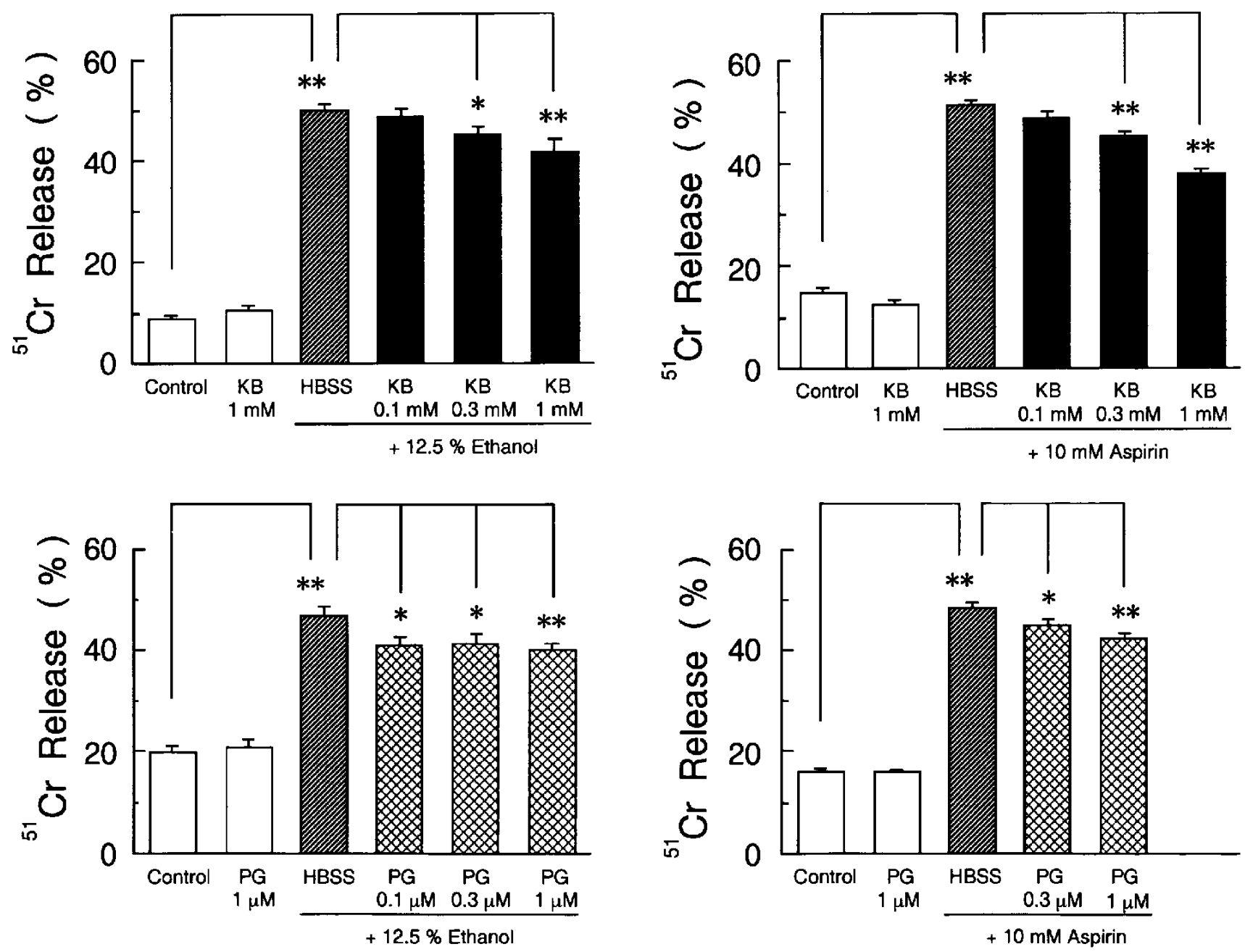

Fig. 4. Effects of KB-5492 (KB) and 16,16-dimethyl prostaglandin $E_{2}(\mathrm{PG})$ on ethanol-induced increase in ${ }^{51} \mathrm{Cr}$ release from cultured rat gastric epithelial cells. Test drugs, dissolved in Hank's balanced salt solution (HBSS, pH 7.4), were added to the cultured cells, and the cells were incubated at $37^{\circ} \mathrm{C}$ for $20 \mathrm{~min}$. Subsequently, ethanol $(12.5 \%$ finally) was added to the cells, and the cells were incubated at $37^{\circ} \mathrm{C}$ for $10 \mathrm{~min}$. Each column represents the mean \pm S.E. of 9 cultures. ${ }^{*} \mathbf{P}<0.05$ and ${ }^{* *} \mathbf{P}<0.01$ represent significant differences (Duncan's test).

of sub-epithelial proliferative zone and rapid restoration of the surface epithelium by the migration from this zone is important to the protective effect of $\mathrm{dmPGE}_{2}$ against ethanol-induced gastric mucosal damage. In the present study, KB-5492 as well as $\mathrm{dmPGE}_{2}$ almost completely prevented both ethanol- and acidified aspirin-induced lesions in the deeper layers corresponding to the proliferative zone (16), which may partly contribute to the mechanism of gastric mucosal protection by KB-5492.

Terano et al. (11) have reported that aspirin-induced damage to cultured gastric epithelial cells evaluated by ${ }^{51} \mathrm{Cr}$ release from ${ }^{51} \mathrm{Cr}$-preloaded cells is highly correlated with that evaluated by the cell viability determined by the

Fig. 5. Effects of KB-5492 (KB) and 16,16-dimethyl prostaglandin $\mathrm{E}_{2}(\mathrm{PG})$ on aspirin-induced increase in ${ }^{51} \mathrm{Cr}$ release from cultured rat gastric epithelial cells. Test drugs plus aspirin ( $10 \mathrm{mM}$ finally), both dissolved in Hank's balanced salt solution (HBSS, pH 5.0), were added to the cultured cells. Subsequently, the cells were incubated at $37^{\circ} \mathrm{C}$ for $2 \mathrm{hr}$. Each column represents the mean \pm S.E. of 9 cultures. ${ }^{*} \mathrm{P}<0.05$ and ${ }^{* *} \mathrm{P}<0.01$ represent significant differences (Duncan's test).

trypan blue exclusion test. In addition, using both methods, they demonstrated the protective effect of $\mathrm{dmPGE}_{2}$ against aspirin-induced damage to cultured gastric epithelial cells (11). In the present study, dmPGE slightly prevented the aspirin-induced increase in ${ }^{51} \mathrm{Cr}$ release from cultured gastric epithelial cells, which is consistent with the result obtained by Terano et al. (11). In addition, dmPGE 2 slightly prevented the ethanol-induced increase in ${ }^{51} \mathrm{Cr}$ release from the cells at the same concentrations as in aspirin-induced damage. These findings confirm that dmPGE ${ }_{2}$ directly protects the gastric epithelial cells in vitro regardless of damaging substances. In a similar manner to dmPGE 2 , KB-5492 slightly prevented both the aspirin- and ethanol-induced increases in ${ }^{51} \mathrm{Cr}$ re- 
lease from the cells. Therefore, KB-5492 is also considered to exert a direct protective effect against the damage to the gastric epithelial cells induced by these necrotizing agents in vitro. However, KB-5492 and $\mathrm{dmPGE}_{2}$ incompletely prevented both the aspirin- and ethanol-induced increases in ${ }^{51} \mathrm{Cr}$ release from the cells. This may explain the incomplete protection by KB- 5492 and $\mathrm{dmPGE}_{2}$ against the microscopic damage to surface epithelial cells in vivo induced by both absolute ethanol and acidified aspirin. Taking these considerations collectively, KB-5492 as well as $\mathrm{dmPGE} \mathrm{P}_{2}$ may exert a direct but limited protective effect on the surface epithelial cells in vivo.

Recently, Lippe and Szabo (19) demonstrated that dmPGE $_{2}$ delays the absorption of ethanol and aspirin from the gastric mucosa, and they suggested that this is involved in the mechanism by which $\mathrm{dmPGE} 2$ protects the gastric mucosa against these damaging agents. Therefore, the effect of KB-5492 on the absorption of these damaging agents from the gastric mucosa also must be studied in the future.

In conclusion, $\mathrm{KB}-5492$ as well as $\mathrm{dmPGE}_{2}$ protects the gastric mucosa in vivo against the damage induced by both ethanol and acidified aspirin. However, KB-5492 does not seem to play a key role in the mechanism of gastric mucosal protection by a direct protective effect on the surface epithelial cells.

\section{Acknowledgments}

The authors are grateful to Miss Y. Sakita and Miss K. Tanaka for their technical assistance.

\section{REFERENCES}

1 Shimohara, K., Niida, H. and Okabe, S.: Effects of KB-5492, 1-(3,4,5-trimethoxybenzyl)-4-((4-methoxyphenyl)oxycarbonylmethyl)piperazine monofumarate monohydrate, on gastric lesions and gastric secretion in rats. Jpn. J. Pharmacol. 53, $275-279$ (1990)

2 Morimoto, Y., Shimohara, K., Oshima, S. and Sukamoto, T.: Effects of the new anti-ulcer agent KB-5492 on experimental gastric mucosal lesions and gastric mucosal defensive factors, as compared to those of teprenone and cimetidine. Jpn. J. Pharmacol. 57, 495-505 (1991)

3 Weber, E., Sonders, M., Quarum, M., McLean, S., Pou, S. and Keana, J.F.W.: 1,3-Di(2-[5- $\left.{ }^{3} \mathrm{H}\right]$ tolyl)guanidine: a selective ligand that labels $\sigma$-type receptors for psychotomimetic opiates and antipsychotic drugs. Proc. Natl. Acad. Sci. USA. 83, $8784-8788$ (1986)

4 Samovilova, N.N., Nagornaya, L.V. and Vinogradov, V.A.: $(+)-\left[{ }^{3} \mathrm{H}\right] \mathrm{SKF} 10,047$ binding sites in rat liver. Eur. J. Pharmacol. 147, 259-264 (1988)

5 Su, T.-P., Schell, S.E., Ford-Rice, F.Y. and London, E.D.: Correlation of inhibitory potencies of putative antagonists for $\mu$ receptors in brain and spleen. Eur. J. Pharmacol. 148, 467-470
(1988)

6 Roman, F.J., Pascaud, X., Chomette, G., Bueno, L. and Junien, J.L.: Autoradiographic localization of sigma opioid receptors in the gastrointestinal tract of the guinea pig. Gastroenterology 97, 76-82 (1989)

7 Roman, F.J., Pascaud, X., Salmon, R., Chomette, G. and Junien, J.L.: Localization and characterization of sigma receptors in the human gastrointestinal tract (abstract). Gastroenterology 100, A662 (1991)

8 Pascaud, X., Defaux, J.P., Roze, C. and Junien, J.L.: Effect of selective sigma ligands on duodenal alkaline secretion in the rat. J. Pharmacol. Exp. Ther. 255, 1354-1359 (1990)

9 Pascaud, X.B., Chovet, M., Soulard, P., Chevalier, E., Roze, C. and Junien, J.L.: Effects of a new $\sigma$ ligand, JO 1784, on cysteamine ulcers and duodenal alkaline secretion in rats. Gastroenterology 104, 427-434 (1993)

10 Terano, A., Ivey, K.J., Stachura, J., Sekhon, S., Hosojima, H., McKenzie, W.N., Krause, W.J. and Wyche, J.H.: Cell culture of rat gastric fundic mucosa. Gastroenterology 83, 1280-1291 (1982)

11 Terano, A., Mach, T., Stachura, J., Tarnawski, A. and Ivey, K.J.: Effect of 16,16 dimethyl prostaglandin $E_{2}$ on aspirin induced damage to rat gastric epithelial cells in tissue culture. Gut 25, 19-25 (1984)

12 Terano, A., Ota, S., Mach, T., Hiraishi, H., Stachura, J., Tarnawski, A. and Ivey, K.J.: Prostaglandin protects against taurocholate-induced damage to rat gastric mucosal cell culture. Gastroenterology 92, 669-677 (1987)

13 Robert, A., Nezamis, J.E., Lancaster, C. and Hanchar, A.J.: Cytoprotection by prostaglandins in rats. Prevention of gastric necrosis produced by alcohol, $\mathrm{HCl}, \mathrm{NaOH}$, hypertonic $\mathrm{NaCl}$, and thermal injury. Gastroenterology 77, 433-443 (1979)

14 Takeuchi, K., Nishiwaki, H., Niida, H. and Okabe, S.: Different effects of cytoprotective drugs on ethanol- and aspirininduced gastric mucosal injury in pylorus-ligated rats. Dig. Dis. Sci. 35, 178-185 (1990)

15 Lacy, E.R. and Ito, S.: Microscopic analysis of ethanol damage to rat gastric mucosa after treatment with a prostaglandin. Gastroenterology 83, 619-625 (1982)

16 Tarnawski, A., Hollander, D., Stachura, J., Krause, W.J. and Gergely, H.: Prostaglandin protection of the gastric mucosa against alcohol injury - A dynamic time-related process. Role of the mucosal proliferative zone. Gastroenterology 88, 334-352 (1985)

17 Schmidt, K.L., Henagan, J.M., Smith, G.S., Hilburn, P.J. and Miller, T.A.: Prostaglandin cytoprotection against ethanolinduced gastric injury in the rat. A histologic and cytologic study. Gastroenterology 88, 649-659 (1985)

18 Ohno, T., Ohtsuki, H. and Okabe, S.: Effects of 16,16dimethyl prostaglandin $E_{2}$ on ethanol-induced and aspirin-induced gastric damage in the rat. Scanning electron microscopic study. Gastroenterology 88, 353-361 (1985)

19 Lippe, 1.Th. and Szabo, S.: New mechanism of mucosal protection: Gastroprotective prostaglandin and sulfhydryls delay the absorption of ethanol and ${ }^{14} \mathrm{C}$-aspirin from the rat stomach. Gastroenterology 98, A79 (1990) 